\title{
Relationship between dental fluorosis and quality of life: a population based study
}

\section{Relação entre fluorose dentária e qualidade de vida: um estudo de base populacional}

\author{
Edgard Michel-Crosato* \\ Maria Gabriela Haye Biazevic* \\ Edgard Crosato**
}

\begin{abstract}
The aim of this study was to verify the prevalence of dental fluorosis in schoolchildren aged 6 to 15 and its possible association with the impacts on their daily activities. This study is observational, cross-sectional and analytical. A total of 513 schoolchildren from the city of Pinheiro Preto, SC, took part in this study. The children were examined by three calibrated dentists, after obtaining a kappa $>0.80$. To assess the prevalence of fluorosis, clinical examinations were performed according to the methodology set forth by the $4^{\text {th }}$ edition of the WHO. To assess the impact of fluorosis on their daily activities, a modified OIDP (Oral Impacts on Daily Performance) was adopted. The statistical analysis used was the Chi-squared test with a $5 \%$ significance level. Of the total number of children examined, 262 (51.1\%) were of the female gender and 251 (48.9\%) were of the male gender. In regard to the prevalence of fluorosis, $94(18.3 \%)$ of the children presented this condition, while 419 children $(81.7 \%)$ presented a normal condition. In regard to the severity of fluorosis, few children presented severe alterations. No association was found between dental fluorosis and gender $(\mathrm{p}=0.646)$, between fluorosis and socioeconomic status $(\mathrm{p}=0.848)$ or between fluorosis and access to public water supply system $(\mathrm{p}=0.198)$. The activities that most affected children's daily performance were: oral hygiene (40.9\%) and food intake or enjoying food (40.4\%). None of the daily activities could be associated with the occurrence of dental fluorosis. The prevalence of dental fluorosis was consonant with the standards found for locations with optimum fluoride content in the water supply. The questionable and very slight levels of fluorosis were the most frequently found, without influence in the quality of life of the schoolchildren participating in the study.
\end{abstract}

DESCRIPTORS: Quality of life; Oral health; Fluorosis, dental.

\begin{abstract}
RESUMO: O objetivo do estudo foi verificar a prevalência de fluorose dentária em escolares de 6 a 15 anos de idade e sua possivel associação com o impacto nas atividades diárias. Trata-se de um censo observacional, transversal, analítico. Participaram do estudo 513 escolares do município de Pinheiro Preto-SC. Os escolares foram examinados por 3 cirurgiões-dentistas devidamente calibrados, após obtenção de kappa > 0,80. Para avaliar a prevalência de fluorose foi realizado exame clínico segundo metodologia da $4^{a}$ edição da OMS. Para verificar os impactos nas atividades diárias foi utilizado o OIDP (Oral Impacts on Daily Performance) modificado. O teste estatístico utilizado foi o do Qui-quadrado, com nível de significância de 5\%. Foram examinados $262(51,1 \%)$ escolares do sexo feminino e 251 (48,9\%) do sexo masculino. Em relação à prevalência de fluorose, 94 (18,3\%) escolares a apresentaram, e $419(81,7 \%)$ apresentaram condições normais. Em relação à gravidade, poucos escolares apresentaram alterações severas. Não foram verificadas associação entre a fluorose dentária e o gênero $(p=0,646)$, fluorose e condição socioeconômica $(p=0,848)$ e tal condição e acesso a abastecimento de água fornecido pela rede geral $(p=0,198)$. As atividades mais citadas que afetaram o desempenho diário foram: limpar os dentes (40,9\%) e se alimentar ou gostar de comida $(40,4 \%)$. Nenhuma atividade diária pôde ser associada com presença de fluorose dental. Verificou-se prevalência de fluorose em consonância com padrões para localidades com teor ideal de flúor na água de abastecimento. As fluoroses questionável e muito leve foram as mais freqüentes, não influenciando a qualidade de vida dos escolares que participaram do estudo.
\end{abstract}

DESCRITORES: Qualidade de vida; Saúde bucal; Fluorose dentária.

\section{INTRODUCTION}

Dental fluorosis has been widely studied in the field of oral epidemiology in the last decades.
With the reduction in the prevalence of caries, the study of fluorosis has been gaining importance

\footnotetext{
* Graduate Program in Collective Health, University of the West of Santa Catarina.

** Graduate Program in Forensic Dentistry, University of São Paulo.
} 
Michel-Crosato E, Biazevic MGH, Crosato E. Relationship between dental fluorosis and quality of life: a population based study.

Braz Oral Res 2005;19(2):150-5.

and dental fluorosis has become more prevalent, as reported in several studies $3,6,7,15,19$.

The reasons for the reduction in caries are many. According to Lima, Cury ${ }^{11}$ (2001), the reduction in dental caries prevalence has been widely associated with the use of fluoride-containing products, even more than as a result of other measures such as brushing, reduction in sugar intake and education.

Several studies have discussed the prevalence of fluorosis in Brazil. Maltz, Farias ${ }^{13}$ (1989) reported that the prevalence of fluorosis in Brazilian cities with optimum levels of fluoride $(0.7 \mathrm{ppm})$ in the water supply is of $22.3 \%$. This prevalence has also been confirmed by other studies ${ }^{2,4,8,14,16,17}$.

Another important factor is that as a result of oral problems, people can have their regular daily activities hindered, such as: reduction in the number of sleeping hours, nonperformance of certain leisure activities, food restrictions, psychological disorders related to the decrease in self-esteem and loss of school or work days ${ }^{12,18}$.

Despite the fact that considerable prevalence of dental fluorosis has been observed ${ }^{16,17}$, its implications in the quality of life of the population is yet unknown. Forte et al. ${ }^{8}(2001)$ reported that the prevalence of dental fluorosis does not constitute a public health problem.

The aim of this study was to verify the prevalence and severity of dental fluorosis, and its possible association with the quality of life of schoolchildren aged 6 to 15 in the city of Pinheiro Preto-SC.

\section{METHOD}

\section{Type of study}

This study is observational, cross-sectional and analytical.

\section{Location}

The town of Pinheiro Preto is located in the state of Santa Catarina, Brazil. According to data from the Brazilian Institute of Geography and Statistics, IBGE ${ }^{10}$ (2000), its total population is of 2,729 inhabitants, and the major economic activity in this town is related to vineyards and the production of homemade wine. The township has two public schools and no private schools. There are no private dental offices in the city; all dental care is provided in a public health clinic and is performed by dentists residing in the neighbor- ing towns. Fluoride has been added to the water for over 10 years and is consumed by $51 \%$ of the population. The University of the West of Santa Catarina (UNOESC) has a system to measure Fluoride content and the reports have indicated a fluoride content of $0.7 \mathrm{ppm}$ in the water. Most children $(95 \%)$ in the 6 to 15 age group use a fluoride-containing dentifrice.

\section{Reference population}

A census was performed in the township of Pinheiro Preto - SC, in which 6 to 15 year-old schoolchildren of both genders were examined (n $=513)$.

\section{Data collection}

The study was carried out in September 2002. The schoolchildren were examined by three calibrated dentists after obtaining a kappa $>0.80$.

In order to assess the socioeconomic status of the subjects, the criteria of the Brazilian Association of Market Research Institutes ${ }^{9}$ (Associação Brasileira de Institutos de Pesquisas Mercadológicas - ABIPEME) were used: schooling and the occupation of the head of the family are worth from 0 to 21 points; the other points are awarded according to the number of durable goods owned by the family - automobile, color television set, radio, refrigerator, freezer, microwave oven, washing machine, etc. -, and the number of rooms in the house, with emphasis on bathrooms, and according to the number of employees rendering services to the household. ABIPEME criteria classifies the population through the sum of the points obtained, as follows: Class E (0 to 19 points); Class D (20 to 34 points); Class C (35 to 58 points); Class B (59 to 88 points); Class A ( 89 points or over). Class A represents the most favored social stratum and Class E the least favored.

For the purpose of socioeconomic assessment, schoolchildren from Classes A and B were considered "most favored" economically and from Classes C, D and E were considered "least favored".

Data concerning dental fluorosis were registered according to codes and criteria of Dean's Index, suggested by the World Health Organization ${ }^{20}$ (1997) and modified by the authors to determine the prevalence of dental fluorosis. The criteria are: $0=$ Normal (the enamel surface is smooth, shinny and presenting a white to off-white coloring); $1=$ Questionable (the enamel presents slight alterations in transparency when compared to normal 
Michel-Crosato E, Biazevic MGH, Crosato E. Relationship between dental fluorosis and quality of life: a population based study.

Braz Oral Res 2005;19(2):150-5.

enamel that may vary from small whitish streaks to occasional spots); 2 = Very light (irregularly dispersed small porous and white opaque stains over the tooth, but covering less than $25 \%$ of the buccal surface); 3 = Light (the white opaque enamel of teeth is more extensive than that for code number 2 , but covering less than $50 \%$ of the total dental surface); 4 = Moderate (the dental enamel surface presents pronounced wear and brown stains, altering the anatomy of the tooth); $5=$ Severe (the enamel surface is deeply affected and hypoplasia is so pronounced that the general shape of the tooth may be affected. There are foveolate or worn areas and the brown stains are generalized; teeth normally present an aspect of corrosion).

For the purpose of data analysis, codes 0 and 1 were classified as "absence of fluorosis" and the remaining codes were classified as "presence of fluorosis".

Oral Impacts on Daily Performance (OIDP) ${ }^{1}$ index was used to measure quality of life. The OIDP is the result of the sum of eight factors of impacted daily activities resulting from oral problems.

The factors are: difficulty in food intake or enjoying food; difficulty pronouncing words; difficulty with oral hygiene; difficulty sleeping or resting; difficulty smiling or laughing; difficulty maintaining emotional stability; difficulty studying; difficulty playing or having fun with other people.

Data were treated using the Stata 8.0 software, chi-squared tests were used to verify possible associations between dental fluorosis, impact on daily activities and social inequities. A 5\% significance level was adopted for all statistical tests performed.

\section{Ethical issues}

Prior to its execution, the project was submitted to the Research Ethics Committee of the Passo Fundo University, RS, and approved.

\section{RESULTS}

The study was conducted with 513 schoolchildren aged 6 to 15 studying in the public school system in the township of Pinheiro Preto (SC).

A total of $262(51.1 \%)$ children of the female gender and 251 (48.9\%) of the male gender were examined. The number of schoolchildren was smaller in the ages of 6 and 15 . The age with the largest frequency was the age of 12 (Table 1).
TABLE 1 - Distribution of schoolchildren according to sociodemographic data (gender, age, socioeconomic status, number of residents in the household, access to fluoride-containing water) and prevalence and severity of fluorosis, Pinheiro Preto-SC, Brazil, 2002.

\begin{tabular}{|c|c|c|c|}
\hline Variable & Category & $\mathrm{n}$ & $\%$ \\
\hline \multirow{2}{*}{ Gender } & Female & 262 & 51.1 \\
\hline & Male & 251 & 48.9 \\
\hline \multirow{10}{*}{ Age (in years) } & 6 & 32 & 6.2 \\
\hline & 7 & 46 & 9.0 \\
\hline & 8 & 58 & 11.3 \\
\hline & 9 & 59 & 11.5 \\
\hline & 10 & 68 & 13.3 \\
\hline & 11 & 58 & 11.3 \\
\hline & 12 & 72 & 14.0 \\
\hline & 13 & 60 & 11.7 \\
\hline & 14 & 44 & 8.6 \\
\hline & 15 & 16 & 3.1 \\
\hline \multirow{2}{*}{$\begin{array}{l}\text { Socioeconomic } \\
\text { status }\end{array}$} & Most favored & 135 & 26.3 \\
\hline & Least favored & 378 & 73.7 \\
\hline \multirow{2}{*}{$\begin{array}{l}\text { Fluoride- } \\
\text { containing water }\end{array}$} & Yes & 264 & 51.5 \\
\hline & No & 249 & 48.5 \\
\hline \multirow{2}{*}{$\begin{array}{l}\text { Number of } \\
\text { residents in the } \\
\text { household }\end{array}$} & 3 or less & 78 & 15.2 \\
\hline & 4 or more & 435 & 84.8 \\
\hline \multirow{2}{*}{$\begin{array}{l}\text { Prevalence of } \\
\text { fluorosis }\end{array}$} & With & 94 & 18.3 \\
\hline & Without & 419 & 81.7 \\
\hline \multirow{4}{*}{$\begin{array}{l}\text { Severity of } \\
\text { fluorosis }\end{array}$} & $\begin{array}{l}\text { Absence of } \\
\text { fluorosis }\end{array}$ & 362 & 70.6 \\
\hline & Questionable & 57 & 11.1 \\
\hline & Very light & 73 & 14.2 \\
\hline & $\begin{array}{l}\text { Light, moderate } \\
\text { and severe }\end{array}$ & 21 & 4.1 \\
\hline
\end{tabular}

According to the ABIPEME index to determine socioeconomic status, $4(0.8 \%)$ participants were found to be in Class E, $9(1.8 \%)$ in Class A, 91 $(17.7 \%)$ in Class D, $126(24.6 \%)$ in Class B and $283(55.2 \%)$ in Class C.

Out of the aggregate of participants, 135 schoolchildren were classified as presenting "most favored" socioeconomic status, while 378 were considered "least favored", representing $26.3 \%$ and $73.7 \%$, respectively (Table 1 ).

Considering the number of occupants in each household, 78 (15.2\%) lived with one or two peo- 
Michel-Crosato E, Biazevic MGH, Crosato E. Relationship between dental fluorosis and quality of life: a population based study.

Braz Oral Res 2005;19(2):150-5.

TABLE 2 - Distribution of schoolchildren according to sociodemographic data (gender, socioeconomic status, access to fluoride-containing water) and prevalence of fluorosis, Pinheiro Preto-SC, Brazil, 2002.

\begin{tabular}{|c|c|c|c|c|c|}
\hline Variable & Category & With Fluorosis & Without Fluorosis & OR [CI 95\%] & $\mathrm{p}$ \\
\hline \multirow{2}{*}{ Gender } & Male & 48 & 203 & 1 & 1 \\
\hline & Female & 46 & 216 & {$\left[\begin{array}{ll}1.11 & (0.69-1.78)\end{array}\right]$} & 0.646 \\
\hline \multirow{2}{*}{ Fluoride-containing water } & With & 54 & 210 & 1 & 1 \\
\hline & Without & 40 & 209 & {$[1.34 \quad(0.84-2.17)]$} & 0.198 \\
\hline \multirow{2}{*}{ Socioeconomic status } & Least favored & 70 & 308 & 1 & 1 \\
\hline & Most favored & 24 & 111 & {$[1.05 \quad(0.62-1.84)]$} & 0.848 \\
\hline
\end{tabular}

There were no statistically significant differences. OR: odds ratio; CI: confidence interval.

ple, while 435 (84.8\%) lived in households with 4 people or more.

In the city, $51.5 \%$ of the population lives in districts served by fluoride-containing water supply, and the schools were supplied with fluoridecontaining water.

In regard to the prevalence of dental fluorosis, $94(18.3 \%)$ children presented some degree of fluorosis and 419 (81.7\%) presented normal conditions. In relation to the severity of fluorosis, few schoolchildren presented severe alterations (Table 1). Fluorosis was observed in $23.3 \%$ of the children aged 6 ; in $51.5 \%$ of the participants aged 7 ; in $54.4 \%$ of the 8 -year-olds; in $62.8 \%$ of the children aged 9 ; in $59.3 \%$ of the children aged 10 ; in $45.0 \%$ of the children aged 11 ; in $58.3 \%$ of the 12 -year-olds; in $61.2 \%$ of the children aged 13 ; in $45.3 \%$ of the children aged 14 ; and in $45.5 \%$ of the schoolchildren aged 15 .

No statistical association was observed between dental fluorosis and gender $(\mathrm{p}=0.646)$, between fluorosis and socioeconomic status $(\mathrm{p}=0.198)$ or between fluorosis and access to public water supply $(\mathrm{p}=0.848)$ (Table 2).

The reported activities affecting most daily activities were: oral hygiene (40.9\%), food intake and enjoying food (40.4\%) (Table 3). No association between dental fluorosis and any of the eight activities investigated was found (Table 4).

\section{DISCUSSION}

The prevalence of dental fluorosis observed in this study was of $18.3 \%$. This number is commensurate with local epidemiological studies performed in locations with adequate levels of fluoride $^{2,4,8,14,16,17}$.

Although half of the population resided in households that did not rely on fluoride-contain-
TABLE 3 - Distribution of schoolchildren according to impact of daily activities resulting from oral problems, Pinheiro Preto-SC, Brazil, 2002.

\begin{tabular}{l|c|c|c}
\hline \hline \multicolumn{1}{c|}{ Variable } & Category & $\mathrm{n}$ & $\%$ \\
\hline \multirow{2}{*}{ Food intake } & With Impact & 207 & 40.4 \\
\cline { 2 - 4 } \multirow{2}{*}{ Speech } & Without Impact & 306 & 59.6 \\
\hline \multirow{2}{*}{ Oral hygiene } & With Impact & 146 & 28.5 \\
\cline { 2 - 4 } & Without Impact & 367 & 71.5 \\
\cline { 2 - 4 } Sleep & With Impact & 210 & 40.9 \\
\hline \multirow{2}{*}{ Smile } & Without Impact & 303 & 59.1 \\
\cline { 2 - 4 } & Without Impact & 414 & 80.7 \\
\hline \multirow{2}{*}{$\begin{array}{l}\text { Emotional } \\
\text { stability }\end{array}$} & With Impact & 123 & 24.0 \\
\cline { 2 - 4 } Study & Without Impact & 390 & 76.0 \\
\cline { 2 - 4 } & With Impact & 153 & 29.8 \\
\hline \multirow{2}{*}{\begin{tabular}{l} 
Entertainment \\
\cline { 2 - 4 }
\end{tabular}} & Without Impact & 360 & 70.2 \\
\cline { 2 - 4 } & With Impact & 153 & 29.8 \\
\cline { 2 - 4 } & Without Impact & 360 & 70.2 \\
\hline \hline
\end{tabular}

ing public water supply, a greater prevalence of fluorosis was not observed in locations with access to public fluoride-containing water supply system. Clark $^{5}$ (1994) reported that in the United States, the prevalence of fluorosis found in locations with fluoride-containing water supply varied from 35 to $60 \%$ and in locations with no fluoride in the water, the prevalence observed was 20 to $45 \%$.

The fluorosis distribution maintained the same prevalence standard when assessed by gender and socioeconomic status.

The impact of the oral condition on daily activities was low, the average OIDP was $10.2 \%$. All topics examined were shown to be important, while 
Michel-Crosato E, Biazevic MGH, Crosato E. Relationship between dental fluorosis and quality of life: a population based study. Braz Oral Res 2005;19(2):150-5.

TABLE 4 - Distribution of schoolchildren according to impact of daily activities for oral problems and prevalence of dental fluorosis, Pinheiro Preto-SC, Brazil, 2002.

\begin{tabular}{|c|c|c|c|c|c|}
\hline Variable & Category & With Fluorosis & Without Fluorosis & OR [CI 95\%] & $\mathrm{p}$ \\
\hline \multirow{2}{*}{ Food Intake } & With Impact & 43 & 164 & 1 & 1 \\
\hline & Without Impact & 51 & 255 & {$\left[\begin{array}{ll}1.31 & (0.81-2.10)\end{array}\right]$} & 0.285 \\
\hline \multirow{2}{*}{ Speech } & With Impact & 32 & 114 & 1 & 1 \\
\hline & Without Impact & 62 & 305 & {$[1.38(0.83-2.28)]$} & 0.184 \\
\hline \multirow{2}{*}{ Oral hygiene } & With Impact & 38 & 172 & 1 & 1 \\
\hline & Without Impact & 56 & 247 & {$[0.97(0.60-1.57)]$} & 0.910 \\
\hline \multirow{2}{*}{ Sleep } & With Impact & 13 & 86 & 1 & 1 \\
\hline & Without Impact & 81 & 333 & {$[0.62(0.30-1.19)]$} & 0.137 \\
\hline \multirow{2}{*}{ Smile } & With Impact & 21 & 102 & 1 & 1 \\
\hline & Without Impact & 73 & 317 & {$[0.89(0.50-1.56)]$} & 0.681 \\
\hline \multirow{2}{*}{$\begin{array}{l}\text { Emotional } \\
\text { stability }\end{array}$} & With Impact & 25 & 128 & 1 & 1 \\
\hline & Without Impact & 69 & 291 & {$[0.82(0.48-1.39)]$} & 0.449 \\
\hline \multirow{2}{*}{ Study } & With Impact & 32 & 121 & 1 & 1 \\
\hline & Without Impact & 62 & 298 & {$[1.11(0.66-1.82)]$} & 0.666 \\
\hline \multirow{2}{*}{ Entertainment } & With Impact & 11 & 37 & 1 & 1 \\
\hline & Without Impact & 83 & 382 & {$\left[\begin{array}{ll}1.37 & (0.60-2.88)]\end{array}\right.$} & 0.387 \\
\hline
\end{tabular}

There were no statistically significant differences. OR: odds ratio; CI: confidence interval.

oral hygiene obtained the highest average amongst all impacts. The related literature emphasizes that oral health is very important in various situations, such as in social gatherings, in meetings in a work environment, on making acquaintances, and in seeking a job ${ }^{12,18}$.

The most reported activities affecting daily performance were: oral hygiene (40.9\%) and food intake and enjoying food (40.4\%). Among the eight activities investigated, no association with dental fluorosis was observed.

\section{REFERENCES}

1. Adulyanon S, Sheiham A. Oral Impacts on Daily Performances. In: Slade GD, editor. Measuring oral health and quality of life. Chapel Hill: University of North Carolina; 1997. p. 151-60.

2. Alcântara CM. Prevalência de fluorose dental em escolares de Curitiba. Rev ABO Nac 1998;6(5):304-7.

3. Biazevic MGH, Araujo ME, Michel-Crosato E. Indicadores de qualidade de vida relacionados com saúde bucal: revisão sistemática. Rev Odontol Vitória 2002;4:13-25.

4. Campos DL, Farias DG, Toledo AO, Bezerra AC. Prevalência de fluorose dentária em escolares de Brasília. Rev Odontol Univ São Paulo 1998;12(3):225-30.

5. Clark DC. Trends in prevalence of dental fluorosis in North America. Community Dent Oral Epidemiol 1994;22(3): 148-52.

\section{CONCLUSION}

It was concluded that the prevalence of fluorosis is in an adequate standard for locations with a supply of fluoride-containing water. The questionable and very light cases of fluorosis were the most frequent ones, without influence on the quality of life of the schoolchildren that participated in the study.

6. Cypriano S, Sousa MLR, Rihs L. Saúde bucal dos préescolares, Piracicaba, Brasil, 1999. Rev Saude Publica 2003;37(2):247-53.

7. Fomon SJ, Ekstrand J, Ziegler EE. Fluoride intake and prevalence of dental fluorosis: trends in fluoride intake with special attention to infants. J Public Health Dent 2000;60(3):131-9.

8. Forte FDS, Freitas CHSM, Sampaio FC, Jardim MCAM. Fluorose dentária em crianças de Princesa Isabel. Pesqui Odontol Bras 2001:15(2):87-90.

9. Gil AC. Métodos e técnicas de pesquisa social. São Paulo: Atlas; 1999.

10. Instituto Brasileiro de Geografia e Estatística. Censo 2000. [citado 2002 Jul 08]. Disponivel em URL: http:// www.ibge.gov.br. 
Michel-Crosato E, Biazevic MGH, Crosato E. Relationship between dental fluorosis and quality of life: a population based study. Braz Oral Res 2005;19(2):150-5.

11. Lima YBO, Cury JA. Fluoride intake by children from water and dentifrice. Rev Saude Publica 2001;35(6):576-81.

12. Locker D, Grushka M. The impact of dental and facial pain. J Dent Res 1987;66(9):1414-7.

13. Maltz M, Farias C. Fluorose dentária em escolares de quatro cidades brasileiras com e sem água artificialmente fluoretada. Rev Fac Odontol Porto Alegre 1989:39(2):18-21.

14. Maltz M, Silva BBE, Schaeffer A, Farias C. Prevalência de fluorose em duas cidades brasileiras, uma com água artificialmente fluoretada e outra com baixo teor de flúor, em 1987 e 1997/98. Rev Fac Odontol Porto Alegre 2000;41(2):51-5.

15. Michel-Crosato E, Biazevic MGH, Crosato E, Saliba O. Desigualdade social e prevalência de cárie em um peque- no município rural do Sul do Brasil. Rev Odontol Vitória 2004;6(2):4-10.

16. Moysés SJ, Moysés ST, Allegretti ACV, Argenta M, Werneck R. Fluorose Dental: ficção epidemiológica? Rev Panam Salud Publica 2002;12(5):339-46.

17. Silva ALCC, Paiva SM. Ocorrência de fluorose dentária em escolares de Belo Horizonte. Rev CROMG 1995;1:49-53.

18. Slade GD, Spencer AJ. Development and evaluation of the Oral Health Impact Profile. Community Dent Health 1994;11(1):3-11.

19. Souza SMD. CPO-D brasileiro aos 12 anos tem redução de 53,22\%. J ABO Nac 1996;8:8.

20. World Health Organization. Oral health surveys: basic methods. $4^{\text {th }}$ ed. Geneva: World Health Organization; 1997.

Received for publication on Nov 25, 2004

Sent for alterations on Feb 25, 2005

Accepted for publication on May 23, 2005 